\title{
Havza ve Arazi Karakteristiklerinin Coğrafi Bilgi Sitemleri (CBS) Yardımıyla Değerlendirilmesi: Pazar Hemşin Deresi Havzası Örneği
}

\author{
Ali Erdem ÖZÇELİK ${ }^{1} \quad$ Turan YÜKSEK ${ }^{*} \quad$ Filiz YÜKSEK ${ }^{2} \quad$ Bülent VEREP ${ }^{3}$ \\ ${ }^{I}$ Recep Tayyip Erdoğan Üniversitesi, Mühendislik ve Mimarllk Fakültesi, Peyzaj Mimarlı̆̆ Bölümü, Rize, Türkiye \\ ${ }^{2}$ Tarım ve Orman Bakanlı̆̆l, Orman Genel Müdürlüğ̈̈, Doğu Karadeniz Ormancllık Arașttrma Enstitüsü Müdürlüğ̈̈, Trabzon, Türkiye \\ ${ }^{3}$ Recep Tayyip Erdoğan Üniversitesi, Su Ürünleri Fakültesi, Temel Bilimler Bölümü, Rize, Türkiye
}

Atıf yapmak için: Özçelik, A.E., Yüksek, T., Yüksek, F. \& Verep, B. (2021). Havza ve Arazi Karakteristiklerinin Coğrafi Bilgi Sitemleri (CBS) Yardımıyla Değerlendirilmesi: Pazar Hemşin Deresi Havzası Örneği. Anadolu Çev. ve Hay. Dergisi, 6(2), 252-260.

How to cite: Özçelik, A.E., Yüksek, T., Yüksek, F. \& Verep, B. (2021). Evaluation of Basin and Land Characteristics using Geographic Information Systems (GIS): The Case of Pazar Hemşin Creek. J. Anatolian Env. and Anim. Sciences, 6(2), 252-260.

iD: https://orcid.org/0000-0001-5877-1738 *iD : https://orcid.org/0000-0003-2964-1760 iD : https://orcid.org/0000- 0003-3275-642X (iD): https://orcid.org/0000- 0003-4238-8325

*Sorumlu yazarın: Turan YÜKSEK

Recep Tayyip Erdoğan Üniversitesi, Mühendislik ve Mimarlık Fakültesi, Peyzaj Mimarlığı Bölümü, Rize, Türkiye \: turan.yüksek@erdogan.edu.tr
Öz: Doğal kaynaklar sürekli etkileşim halinde olan ekosistemlerdir. Bu ekosistemlerin planlanması bütünleşik havza planlanma ilkelerine göre yapılmalıdır. Ancak Rize il ölçeğindeki doğal kaynak planlama ve altyapı çalışmalarında bu hususun layıkıyla dikkate alındığı pek söylenemez. Bu çalışmanın amacı Pazar Hemşin havzası bazı havza karakteristikleri ile arazilerin yükselti kademeleri, eğim, bakı ve jeolojik yapıya göre dağılımlarının Coğrafi Bilgi Sistemi yardımıyla ortaya konulmasıdır. Araştırma sonucuna göre araştırma alanı 21216 hektar ve ortalama eğimi \% 30,97'dir. Yükselti kademelerine göre en geniş arazi varlığı 4153,35 hektar $(\% 19,58)$ ile 901-1200 m yükseltiler arasında ve en az arazi varlığ 1633,26 hektar (\% 2,98) ile 2100 2400 m yükseltileri arasında olduğu belirlenmiştir. Eğim ve bakı faktörlerine göre arazilerin \% 63,14'ü gölgeli bakılar üzerinde ve \% 36,86'sı güneșli bakılar üzerindedir. Eğime göre en genis ziraat alanı \% 38,35 ile \% 11-20 eğim gurubunda yer almaktadır. Orman arazilerinin \% 30,44'ü asidik kayaçlar, \% 69,43'ü nötr kayaçlar ve \% 0,13 ile alüvyon alanlar üzerindedir. Kayaç türlerine göre en geniş orman varlığ $\%$ 30,33 ile granit kayaçlar üzerindedir. Yerleșim yerlerinin \% 44,55'i asidik kayaçlar, \% 54,37'si nötr kayaçlar ve \% 1,08'i ile alüviyon alanlar üzerindedir. Mevcut yerleşim yerlerinin \% 63,99'u gölgeli bakılar üzerinde, \% 36,01'i güneșli bakılar üzerindedir. Havza genelinde yerleșim yeri kullanımlarında gölgeli bakılar baskın durumdadır. Yerleşim yerlerinin seçimi, yol ve alt yapı çalışmaları ile tarım arazilerinin kullanılmasında yukarıda ortaya konulan havza özelliklerinin dikkate alınması hem sorunların çözümlenmesi hem de sürdürülebilir havza yönetimi için faydalı olabilir.

\section{Evaluation of Basin and Land Characteristics using Geographic Information Systems (GIS): The Case of Pazar Hemşin Creek}

*Corresponding author's: Turan YÜKSEK

Recep Tayyip Erdoğan University, Faculty of Engineering\& Architecture, Department of Landscape Architecture, Rize, Turkey 凶: turan.yüksek@erdogan.edu.tr

\begin{abstract}
Natural resources are ecosystems in constant interaction. Planning of these ecosystems should be done according to integrated watershed management principles. However, it cannot be said that this issue is taken into account in natural resource planning and infrastructure works in Rize. The aim of this study is to determine some basin characteristics of Pazar Hemsin basin and the distribution of lands according to elevation, slope, aspect and geological structure using of Geographical Information System. As a result of the study, the drainage area of the study area is 21216 hectares and its average slope is $30.97 \%$. According to the elevation steps, it was determined that the largest land was 4153.35 hectares $(19.58 \%)$ in $901-1200 \mathrm{~m}$ elevation steps, while the least amount of land was 633.26 hectares $(2.98 \%)$ in $2100-2400 \mathrm{~m}$ elevation steps. According to the slope and aspect factors, $63.14 \%$ of the lands are on shady views and $36.86 \%$ are on sunny views. According to the slope, the largest agricultural area (38.35\%) is in the slope group of $11-20 \% .30 .44 \%$ of forest lands are on acidic rocks, while $69.43 \%$ on neutral rocks and $0.13 \%$ on alluvium areas. According to the rock types, the largest forest area is on granite rocks with $30.33 \% .44 .55 \%$ of the settlements are on acidic rocks, while $54.37 \%$ on neutral rocks and $1.08 \%$ on alluvium areas. $63.99 \%$ of the settlements are on shady views, while $36.01 \%$ are on sunny views. Shaded views are dominant in the choice of settlement. Take into basin characteristics in the selection of settlements, road and infrastructure works and the use of agricultural lands may be beneficial for both solving problems and sustainable basin management in Pazar Hemşin River Basin.
\end{abstract}

Keywords: Aspect, elevation steps, geographical information systems, geological structure, slope. 


\section{GíRíş}

Hızlı sanayileşme ve teknolojik gelişmeler insanoğlunun hayatındaki işlerin daha kolay ve daha hızlı bir şekilde yapılmasına imkan verirken; endüstriyel faaliyetler ve artan tüketimler sonucunda çevre ve doğal kaynaklar üzerinde çok ciddi baskılar oluşmaya devam etmektedir. Dünya genelinde (Anonim, 2017; Shen ve Hwang, 2019) ve ülkemizde (Eroğlu vd., 2019; Yazıcı vd., 2019) meydana gelen küresel iklim değişimi ve afetlerin yıllar itibariyle artmaya devam etmesi insanın çevre üzerindeki olumsuz etkilerinin artarak devam ettiğinin açık bir kanıtı olarak kabul edilebilir.

Dünya coğrafyasında münferit halde havzalar olduğu gibi; bir havza içerisinde birden çok alt havzaların olduğu farklı büyüklük ve şekillerde havzalarda mevcuttur. Havzalar, insanların her türlü çalışmalarını yürüttüğü doğal ve dinamik sistemlerdir (Yüksek vd., 2019). Havzalar hem doğal süreçlere hem de insan faaliyetlerine karşı açık sistemler olduğu için sürekli değişime uğramaktadır. Havzalardaki değişim ve gelişimler bazen havzaların ekolojik dengesine katkı sağlarken; çoğunlukla havzalardaki ekolojik dengenin bozulmasına neden olmaktadır. Havzaların sahip olduğu karakteristik özelliklerinin bilinmemesi veya doğru bir şekilde algılanmaması, aynı havza içerisinde olan kentsel ve kırsal alanların birbirlerinden bağımsız bir şekilde ele alınarak planlanması havzalardaki sorunların daha karmaşık bir hale gelmesine neden olmaktadır. Havza içerisinde yukarıdan aşağıya doğru uygulanması gereken dere 1 slah, sel ve taşkın projelerinin havzanın çıkış (mansap) noktasına yakın alanlarda uygulanması, mansap bölümündeki dere yatağının daraltılması, arazi yetenek sınıfları, arazinin eğimi, toprağın heyelan duyarlılığı dikkate alınmadan arazi kullanım şekillerinin veya yol planlamalarının yapılması ve bunun gibi hususlar planlamacıların havzaları ve havza karakteristik özelliklerinin doğru bir şekilde algılamadıklarına örnek olarak verilebilir.

Dünya genelinde olduğu gibi ülkemizdeki artan nüfusun taleplerinin karşılanmasında çevre ve doğal kaynakların doğru bir şekilde planlanması ve yönetimi oldukça önemli bir konudur. Kentsel ve kırsal alandaki tüm çevresel faktörlerin doğru biçimde algılanabilmesi ve koruma-kullanma dengesine uygun (Yüksek vd., 2008) bir şekilde kullanılabilmesi ancak entegre havza planlama ve yönetim modelinin (Yüksek, 2004) uygulanması ile mümkündür. Havza sınırlarının belirlenmesi, havzaların çeşitli havza karakteristik özellikleri yanı sıra arazi kullanım şekilleri, sosyo-ekonomik yapı, tarihi ve kültürel varlıkların belirlenmesi entegre havza planlama ve yönetim modelinin doğru bir şekilde oluşturulabilmesi için oldukça önemlidir.

Ülkemizdeki farklı havzaların sahip olduğu havza karakteristiklerinin belirlenmesi ile alakalı direkt veya indirekt olarak yapılmış çalışmalar (Akkaya Aslan vd.,
2004; Göl \& Dengiz, 2007; Dengiz \& Göl, 2008; Yüksel vd., 2008; Elibüyük \& Yılmaz, 2010; Y1lmaz vd., 2011; Dindaroğlu vd., 2012; Bağdatlı \& Öztürk, 2014; Taş, 2016; Reis vd., 2016; Göl vd., 2017; Reis vd., 2017a; Reis vd., 2017b; Yüksel vd., 2018; Reis \& Dindaroğlu, 2018; Yüksek vd., 2019; Bilgili vd., 2020; Reis \& Dindaroğlu, 2020; Dutal \& Reis, 2020; Yazıcı ve İnan, 2020; Yüksek vd., 2020) olmakta birlikte; ülkemiz genelindeki havza sayıları dikkate alındığında konuyla alakalı yapılmış olan çalışmaların yetersiz olduğu ortaya çıkmaktadır. Bu nedenle havza karakteristikleri ve havzalardaki arazilerin fizyografik özelliklere göre dağılımlarının ortaya konulması, başarılı entegre havza yönetim planlarının oluşturulması için oldukça gereklidir. Bu çalışmanın araştırma hipotezi: Tüm akarsu havzalarının havza karakteristikleri aynıdır ve arazilerin dağılımında fizyografik özelliklerin etkisi yoktur.

$\mathrm{Bu}$ araştırmanın amacı Pazar-Hemşin deresi havzasının havza karakteristikleri ve arazilerin bazı fizyografik özelliklere göre dağılımlarının coğrafi bilgi sitemleri ile tespit edilmesidir.

\section{MATERYAL VE METOT}

Araştırma Sahası Coğrafi Konumu ve Bazı İklim Özellikleri: Pazar Hemşin Deresi yağış havzası (Şekil 1), Rize iline ortalama $38 \mathrm{~km}$ uzaklıkta, 405244 - 411121 kuzey enlemleri ile 4045 26-41 0204 doğu boylamları arasında yer almaktadır (Yüksek, 2001).

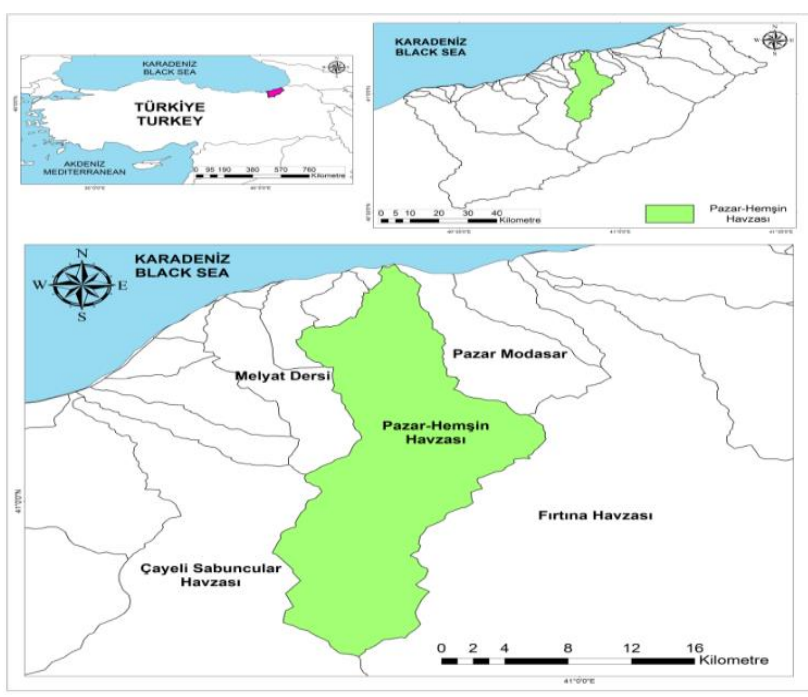

Şekil 1. Pazar Hemşin Deresi havzası coğrafi (konumsal) gösterimi.

Figure 1. The geographical (spatial) representation of the Pazar Hemşin Creek basin.

Pazar Hemşin Deresi Havzası deniz seviyesinden itibaren güneye doğru 2400 m yükseltiye kadar erişmektedir. Yağış havzası iklim verilerinin yorumlanmasında Pazar istasyonu 1990-2019 yıllarına ait verilerden yararlanılmıştır. 
Araştırma alanında yıllık ortalama maksimum sıcaklık 25,55 ${ }^{\circ} \mathrm{C}$, ortalama sicaklık $13,91{ }^{\circ} \mathrm{C}$ ve ortalama minimum sicaklık $5,94{ }^{\circ} \mathrm{C}$ 'dir. Ortalama en düşük minimum sıcaklık Şubat ($\left.1,89{ }^{\circ} \mathrm{C}\right)$, ve ortalama en sicak ayı ağustostur $\left(22,88{ }^{\circ} \mathrm{C}\right)$ (Şekil 2a).

Yağışın zaman bağlı değişimi $\mathrm{y}=4,0964 \mathrm{x}^{2}-$ $34,179 \mathrm{x}+185,4, \mathrm{R}^{2}=0,7617$ şeklinde ve polinomvari bir ilişki içindedir (Şekil 2b). Pazar Hemşin deresi havzasındaki aylık toplam yağış ocak ayından nisan ayına kadar doğrusal bir şekilde azalmakta, daha sonra ekim ayına kadar artmakta ve sonra tekrar azalmaktadır (Şekil 2b). Yıl içinde en yağışlı ay $288 \mathrm{~mm}$ ile ekim, en az yağışın olduğu ay $78 \mathrm{~mm}$ ile nisandır (Yüksek vd., 2020). Yıl içinde Rize genelinde olduğu gibi biri az yağışlı (ilkbahar), diğeri çok yağışı (yaz, sonbahar ve kış) yağış rejimi hakimdir (Yüksek, 2001). Thornthwaite yöntemine göre Pazar Hemşin havzasının iklim tipi (A B'1 r a') rumuzu ile ifade edilen çok nemli, orta sıcaklıkta (mezotermal), su noksanı olmayan veya pek az olan denizel iklim özelliklerine sahiptir (Yüksek, 2017).

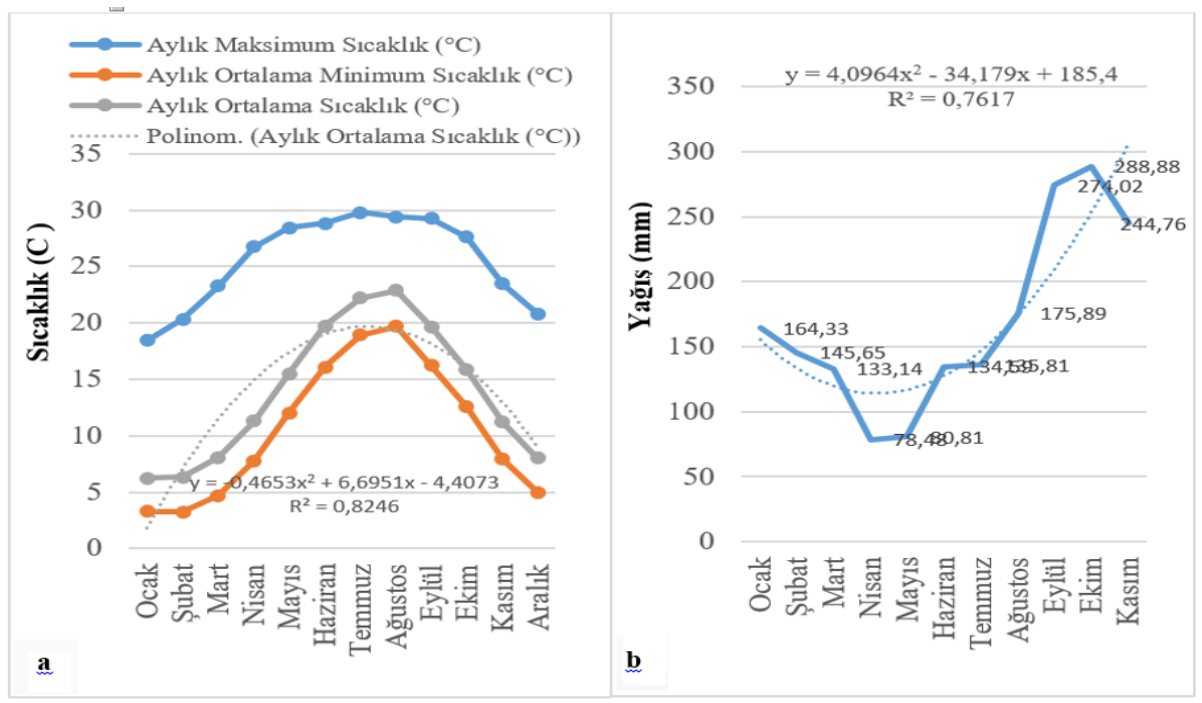

Şekil 2. Pazar Meteoroloji İstasyonu Sıcaklık (a) ve yağış (b) değerlerinin aylık değişimi (Gözlem dönemi: 1990-2019).

Figure 2. Monthly variation of temperature (a) and precipitation (b) of Pazar Meteorology Station (Observation period: 1990-2019).

Havza veri setinin oluşturulmast ve havza karakteristiklerinin belirlenmesi: Coğrafi Bilgi Sistemleri kullanılarak oluşturulan veri seti ve havza karakteristik özelliklerinin belirlenmesinde kullanılan formüller yardımıyla Pazar Hemşin Deresi Havza karakteristik özellikleri hesaplanmıştır (Yüksek vd., 2019; Yüksek vd., 2020) (Tablo 1). Bu amaçla Pazar Hemşin deresi yağış havzasının sınırları ArcGIS 10.5 programı yardımıyla çizildikten sonra arazi karakteristiklerinin belirlenmesi ve tanımlanmasına yönelik veri setleri oluşturulmuştur. Havza genelinde veri setleri raster ve vektör veri yapısında olmak üzere iki alt grupta oluşturulmuştur. Buna ilaveten PazarHemşin havzası arazi karakteristiklerinin belirlenmesi kapsamında Coğrafi Bilgi Sistemleri (CBS) kullanılarak konumsal veri altyapısı oluşturulmuştur. Uygulama kapsamında CBS yazılımı olan ArcGIS 10.5 programı kullanılarak veri setlerine dayalı alt bileşen veri gruplarının sınıflandırılması uygulaması gerçekleştirilmiştir. Sınıflandırma uygulamasında yükselti, eğim, bakı, jeoloji ve orman amenajmanı veri setleri kullanılmıştır.

\section{BULGULAR}

Pazar Hemşin deresinin drenaj alanı 21600 hektar olup, yükselti kademelerine göre en geniş arazi varlığ
Tablo 1. Pazar Hemşin Deresi Havza karakteristik özelliklerinin hesaplanmasında kullanılan yöntemler (Özhan, 2004; Yüksek vd, 2019, Yüksek vd., 2020).

Table 1. Methods used to calculate the watershed characteristics of Pazar Hemşin Creek Basin (Özhan, 2004; Yüksek vd, 2019, Yüksek vd., 2020).

\begin{tabular}{|c|c|c|}
\hline $\begin{array}{c}\text { Havza } \\
\text { Karakteristikleri }\end{array}$ & Hesaplama Yöntemi & $\begin{array}{l}\text { Sembollerin } \\
\text { Açıklaması }\end{array}$ \\
\hline Havza Form Faktörü & $\mathrm{F}=\frac{\mathrm{A}}{-2}$ & F: Form faktörü, \\
\hline Havzanın Şekil & $\mathrm{F}=\frac{L^{2}}{-}$ & A: Havza Alanı \\
\hline Faktörü & & $\left(\mathrm{Km}^{2}\right)$, \\
\hline $\begin{array}{l}\text { Havzanın Dairesellik } \\
\text { Oranı (Rc) }\end{array}$ & $\mathrm{Rc}=\frac{4 \pi A}{P^{2}}$ & $(\mathrm{~km})$ \\
\hline Havzanın Eğimi (Sg) & $\mathrm{Sg}=1.571 \frac{D X N}{\Sigma \mathrm{L}}$ & $\begin{array}{l}\text { Rc: Dairesellik } \\
\text { Oranı }\end{array}$ \\
\hline $\begin{array}{l}\text { Maksimum Reliyef } \\
(\mathrm{H})\end{array}$ & $\mathrm{H}=\mathrm{X}-\mathrm{Y}$ & $\begin{array}{l}\text { P: Havzanın çevresi } \\
(\mathrm{km})\end{array}$ \\
\hline Oransal Reliyef (Rho) & $\mathrm{Rho}=\frac{\mathrm{H}}{\mathrm{D}}$ & $\Sigma$ L: Eğri \\
\hline Havzanın Ortalama & $\mathrm{Hy}=\frac{a 1 b 1+a 2 b 2+\cdots \ldots+a+a n b n}{A}$ & $\begin{array}{l}\text { uzunluklarının } \\
\text { toplamı }(\mathrm{m})\end{array}$ \\
\hline & & $\begin{array}{l}\text { H: Havzanın } \\
\text { maksimum reliyefi } \\
\text { X: Havzanın en } \\
\text { yüksek noktası (m), } \\
\text { Y: Havzanın en } \\
\text { düşük noktası (m) } \\
\text { a: iki eşyükselti } \\
\text { arasındaki alan (ha), } \\
\text { h: İki eşyükselti } \\
\text { eğrisi arasındaki } \\
\text { yükselti (m) }\end{array}$ \\
\hline
\end{tabular}

4153,35 hektar $(\% 19,58)$ ile 901-1200 m yükseltiler arasında ve en az arazi varlığ 633,26 hektar (\% 2,98) ile 2100-2400 m yükseltileri arasında olduğu belirlenmiştir (Tablo 2, Şekil 
3a). Arazi varlığının \% 50,74’ü 900 metrenin altındadır. 0$900 \mathrm{~m}$ yükseltilere arasındaki arazilerin yükselti basamaklarına göre dağılımı düzensiz seyrederken; 900 metre yükselti kademesinden sonra yükselti basamaklarına göre arazilerin dağılımı doğrusal biçimde azalmaktadır (Tablo 2).

Bakıya göre en geniş arazi varlığı 3759,35 hektar (\% 17,72) ile kuzeybatı bakıda, en az arazi varlı̆g 966,17 hektar $(\% 4,55)$ ile güney bakıdadır. Havza genelindeki arazilerin \% 62,98'i gölgeli bakılar üzerinde ve \% 37,02'si güneşli bakılar üzerinde olup, arazi varlığının dağılımında gölgeli bakılar baskın durumdadır (Tablo 2, Şekil 3b). Doğu ve batı bakıda en geniş arazi varlığı $0-300 \mathrm{~m}$ yükselti kademesinde, güney ve güneybatı bakıda en geniş arazi varlı̆̆1 1200-1500 m yükselti kademesinde iken; kuzey, kuzeydoğu, kuzeybatı ve güneydoğu bakılarda en geniş arazi varlı̆̆ 900-1200 m yükselti kademesindedir (Tablo 2).

Tablo 2. Pazar Hemşin Deresi Havzasındaki arazi varlığının (ha) bakı ve yükselti kademelerine göre değişimi.

Table 2. Change of lands (ha) in Pazar Hemşin Creek Basin according to aspect and elevation.

\begin{tabular}{|c|c|c|c|c|c|c|c|c|c|}
\hline \multirow{2}{*}{ Bak1 } & \multicolumn{8}{|c|}{ Yükselti Gurubu (m) } & \multirow[t]{2}{*}{ Toplam } \\
\hline & $0-300$ & $301-600$ & $601-900$ & $901-1200$ & $1201-1500$ & $1501-1800$ & $1801-2100$ & $2100-2400$ & \\
\hline $\mathrm{D}$ & 977,5 & 593,98 & 446,37 & 537,78 & 165,00 & 184,4 & 205,98 & 81,51 & $3.192,51$ \\
\hline K & 236,86 & 385,73 & 619,13 & 794,33 & 366,19 & 447,96 & 361,49 & 122,99 & $3.334,66$ \\
\hline $\mathrm{KD}$ & 480,48 & 776,13 & 555,54 & 540,22 & 164,65 & 134,05 & 397,48 & 26,33 & $3.074,85$ \\
\hline $\mathrm{KB}$ & 464,14 & 644,05 & 735,44 & 772,37 & 305,62 & 425,81 & 239,86 & 172,03 & $3.759,35$ \\
\hline G & 130,46 & 93,04 & 125,73 & 187,08 & 229,45 & 84,84 & 59,62 & 55,96 & 966,17 \\
\hline GD & 243,54 & 311,21 & 182,47 & 520,81 & 246,13 & 56,49 & 54,42 & 51,82 & $1.666,88$ \\
\hline GB & 189,8 & 332,33 & 338,16 & 241,83 & 358,78 & 119,66 & 46,02 & 48,38 & $1.674,95$ \\
\hline B & 859,19 & 585,31 & 459,13 & 558,94 & 619,51 & 328,67 & 61,66 & 74,25 & $3.546,63$ \\
\hline Toplam & $3.581,96$ & $3.721,77$ & $3.461,96$ & $4.153,35$ & $2.455,32$ & $1.781,87$ & $1.426,52$ & 633,26 & $21.216,00$ \\
\hline Alan (\%) & 16,88 & 17,54 & 16,32 & 19,58 & 11,57 & 8,4 & 6,72 & 2,98 & 100 \\
\hline
\end{tabular}

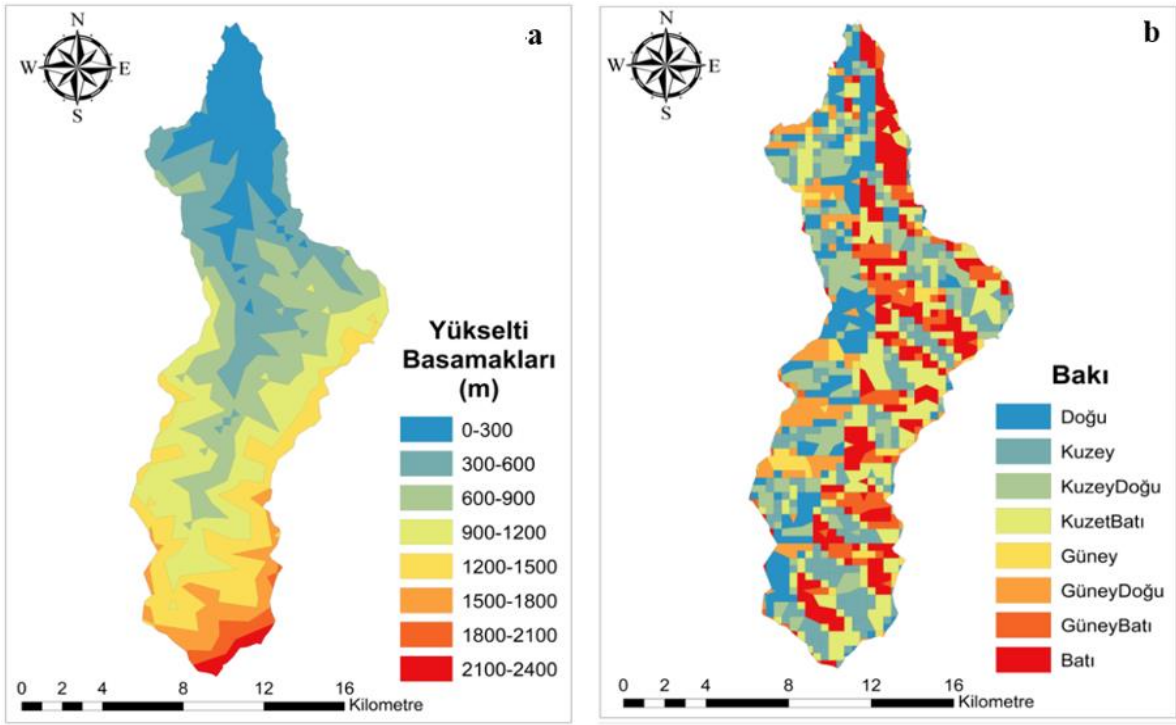

Şekil 3. Pazar Hemşin Deresi Havzası yükselti basamakları (a) ve bakıya göre (b) arazilerin dağılımı.

Figure 3. Distribution of the lands in Pazar Hemşin Creek Basin according to the elevation steps (a) and the aspect (b).

Pazar Hemşin havzasının ortalama eğimi \% 30,97'dir. Eğim ve bakıya göre en geniş arazi varlı̆̆ 1 3751,09 hektar $(\%$ 17,68) ile kuzeybatı bakıda, en az arazi varlığ 1657,27 hektar (\% 7,81) ile güneydoğu bakıdadır (Tablo 3, Şekil 4a). Eğim ve bakı faktörlerine göre arazilerin $\%$ 63,14'ü gölgeli bakılar üzerinde ve \% 36,86'sı güneşli bakılar üzerindedir (Tablo 3).

Eğim gurupları ve yükselti basamaklarına göre en geniş arazi varlı̆̆ $\%$ 25,89 ile \% 21-30 eğim gurubunda yer almaktadır. Yükselti basamaklarına göre \% $0-10$ eğim gurubundaki arazi varlığı toplam arazi varlığının $\% 10,05$ 'i kadardır (Tablo 4), 0-10 eğim gurubundaki arazilerin \% 52,98'i 0-300 m yükseltileri arasindadır.

Orman arazilerin jeolojik yapıya göre dağılımlarında ilginç bir durum vardır. Orman arazilerinin \% 30,44'ü asidik kayaçlar, \% 69,43'ü nötr kayaçlar ve \% 0,13 ile alüvyon alanlar üzerindedir (Şekil $4 \mathrm{~b}$ ve 5). Kayaç türlerine göre en geniş orman varlığı \% 30,33 ile granit kayaçlar üzerindedir.

Tarım arazilerinin \% 12,02'si asidik kayaçlar, \% 83,13'ü'ü nötr kayaçlar ve \% 4,85'i ile alüvyon alanlar üzerindedir (Şekil 4b ve 5). Yerleşim yerlerinin \% 44,55'i asidik kayaçlar, \% 54,37'si nötr kayaçlar ve \% 1,08'i ile alüvyon alanlar üzerindedir (Şekil $4 \mathrm{~b}$ ve 5).

Havza içerisinde en fazla ormanlık alan \% 14,8 ile kuzeybatı bakıda, en az orman varlığı ise \% 3,51 ile güney bakıdadır. Orman arazi varlığının \% 63,76'sı gölgeli bakıda, \% 36,24'ü ise güneşli bakılar üzerindedir (Şekil 6). 
Tablo 3. Eğim guruplarına göre bakılardaki arazi varlığı (ha).

Table 3. Lands in aspects by slope groups (ha).

\begin{tabular}{|c|c|c|c|c|c|c|c|c|c|}
\hline Eğim (\%) & $\mathrm{D}$ & $\mathrm{K}$ & KD & KB & $\mathrm{G}$ & GD & GB & $\mathrm{B}$ & Toplam \\
\hline $0-10$ & 335,90 & 167,96 & 325,35 & 259,59 & 181,43 & 142,31 & 224,97 & 406,02 & $2.043,52$ \\
\hline 11_20 & 951,76 & 640,77 & 773,54 & 748,92 & 170,31 & 417,28 & 216,99 & 950,36 & $4.869,92$ \\
\hline 21_30 & 962,93 & 925,69 & 919,90 & $1.198,96$ & 244,21 & 378,34 & 490,14 & 941,60 & $6.061,77$ \\
\hline 31_40 & 679,05 & 941,33 & 707,44 & 761,31 & 213,36 & 482,66 & 445,49 & 765,50 & $4.996,13$ \\
\hline $51-60$ & 18,80 & 165,31 & 18,80 & 246,95 & 33,24 & 20,02 & 69,99 & 141,13 & 714,23 \\
\hline Alan (ha) & $3.251,26$ & $3.326,44$ & $3.066,63$ & $3.751,09$ & 966,17 & $1.657,27$ & $1.666,83$ & $3.530,35$ & $21.216,00$ \\
\hline Alan (\%) & 15,32 & 15,68 & 14,45 & 17,68 & 4,55 & 7,81 & 7,86 & 16,64 & 100,00 \\
\hline
\end{tabular}

Tablo 4. Eğim guruplarına (\%) göre yükselti basamaklarındaki arazi varlığı (ha).

Table 4. Land presence (ha) at elevation steps according to slope levels (\%).

\begin{tabular}{|c|c|c|c|c|c|c|c|c|c|c|}
\hline \multirow[b]{2}{*}{ Eğim (\%) } & \multicolumn{8}{|c|}{ Yükselti Kademeleri (m) } & \multirow{2}{*}{$\begin{array}{c}\text { Toplam Alan } \\
\text { (ha) }\end{array}$} & \multirow{2}{*}{$\begin{array}{c}\text { Alan } \\
(\%)\end{array}$} \\
\hline & $0-300$ & $301-600$ & $601-900$ & $901-1200$ & $1201-1500$ & $1501-1800$ & $1801-2100$ & $2101-2400$ & & \\
\hline $0 \_10$ & $1.129,33$ & 333,83 & 174,6 & 129,99 & 124 & 145,5 & 86,33 & 7,7 & $2.131,28$ & 10,05 \\
\hline 11_20 & $1.650,50$ & $1.139,40$ & 675,84 & 722,59 & 309,16 & 259,64 & 128,13 & 58,06 & $4.943,32$ & 23,30 \\
\hline 21_30 & 736,67 & $1.254,70$ & $1.180,70$ & 950,65 & 765,56 & 330,9 & 133,4 & 139,8 & $5.492,38$ & 25,89 \\
\hline 31_40 & 55,95 & 784,3 & $1.018,34$ & $1.362,07$ & 655,8 & 620,25 & 287,4 & 88,5 & $4.872,61$ & 22,97 \\
\hline 41_50 & 9,51 & 209,53 & 370,65 & 857,42 & 470,8 & 310,98 & 403,26 & 118,31 & $2.750,46$ & 12,96 \\
\hline 51_60 & 0 & 0 & 41,83 & 130,63 & 130 & 114,6 & 388 & 220,89 & $1.025,95$ & 4,84 \\
\hline Toplam & $3.581,96$ & $3.721,77$ & $3.461,96$ & $4.153,35$ & $2.455,32$ & $1.781,87$ & $1.426,52$ & 633,26 & $21.216,01$ & 100 \\
\hline
\end{tabular}

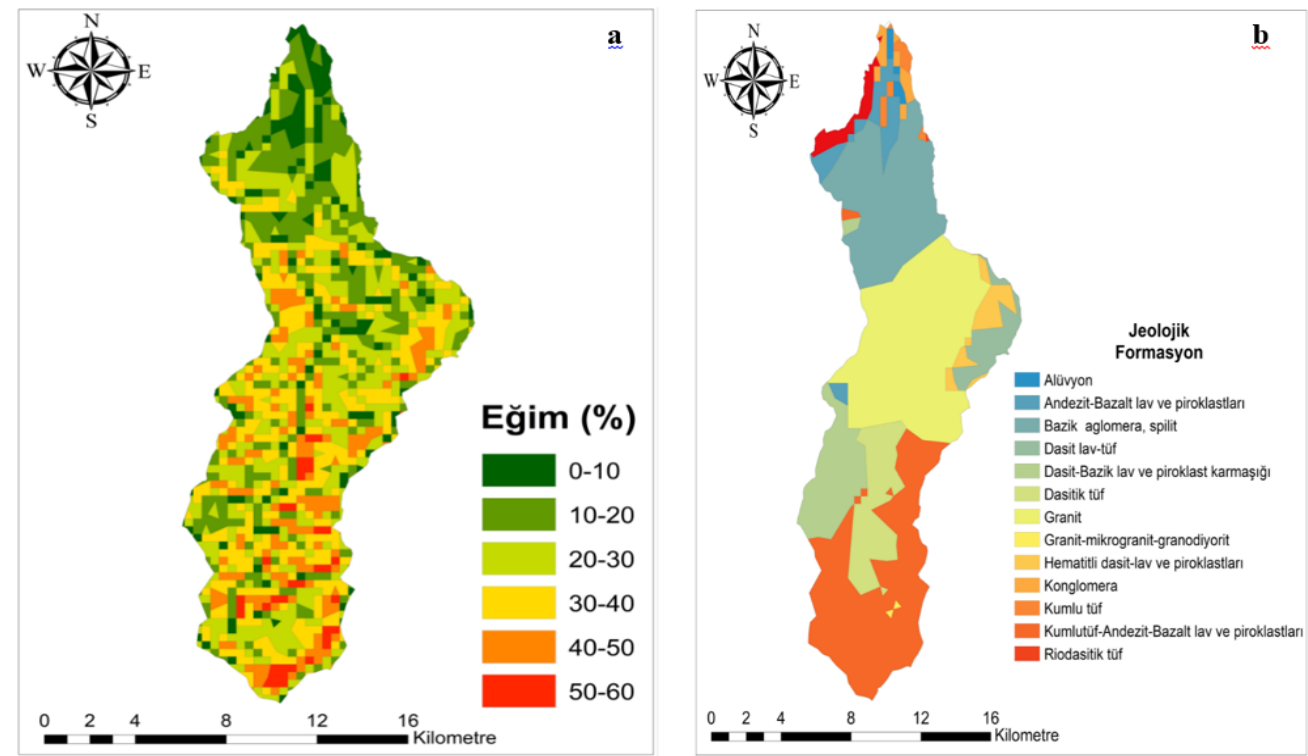

Şekil 4: Pazar Hemşin Havzasındaki arazilerin eğim gurupları (4a) ve jeolojik formasyonlara (4b) göre dağılımları.

Figure 4: Distribution of the lands in the Pazar Hemsin Basin according to slope groups (4a) and Geological Formations (4b).

Havza genelinde yerleşim yeri kullanımlarında gölgeli bakılar baskın durumdadır. Mevcut yerleşim yerlerinin \% 63,99'u gölgeli bakılar üzerinde, \% 36,01'i güneşli bakılar üzerindedir. Havza içerisinde en geniş yerleşim yeri \% 23,28 ile doğu bakıda, en az yerleşim yeri $\%$ 3,1 ile güney bakıdadır (Şekil 7).

Eğime göre yerleşim alanlarının oransal değeri önce artmakta, daha sonra tekrar azalmaktadır. En geniş yerleşim alanı \% 11-20 eğim gurubunda, en düşük yerleşim alanı \% 0,08 ile \% 51-60 eğim gurubundadır. Yerleşim alanları ile eğim gurupları arasında $\mathrm{R}^{2}=0,831$ ve $\mathrm{y}=$ $2,1523 \mathrm{x}^{2}+9,6437 \mathrm{x}+15,559$ şeklinde polinomvari bir ilişki belirlenmiştir (Şekil 7). Eğime göre en geniş ziraat alanı $\%$ 38,35 ile \% 11-20 eğim gurubunda yer almaktadır. Tarım arazilerinin \% 58,95'i \%11-30 eğim gurubunda yer almaktadır (Şekil 8). Tarım arazilerinin eğime göre dağılımları $R^{2}=0,695$ ile $y=-0,5675 x^{2}-1,8389 x+31,71$ şeklinde ve polinomvari bir ilişkiye sahiptir (Şekil 8).

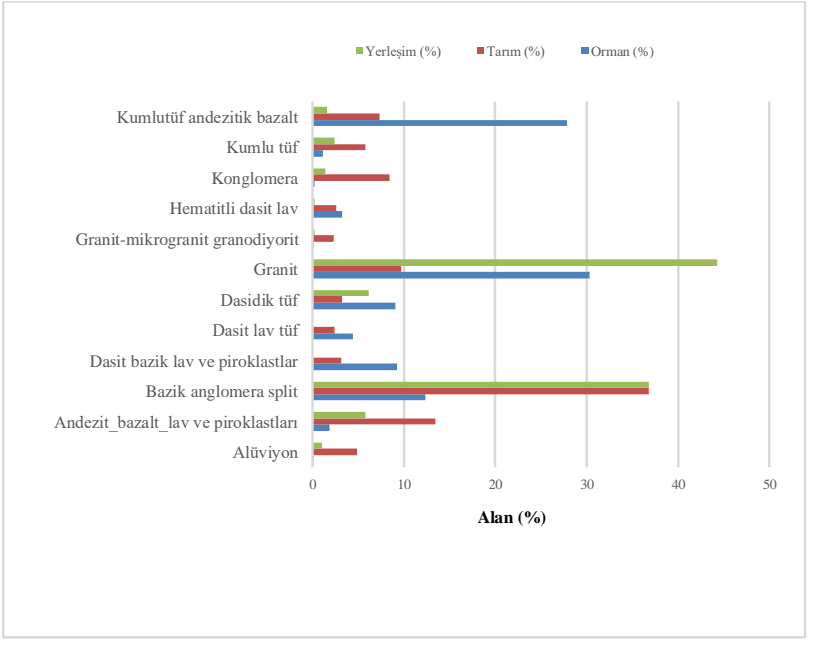

Şekil 5. Orman, Tarım ve İskan alanlarının kayaç guruplarına göre dağılımları.

Figure 5. Distribution of Forest, Agriculture and Residential areas by rock groups. 


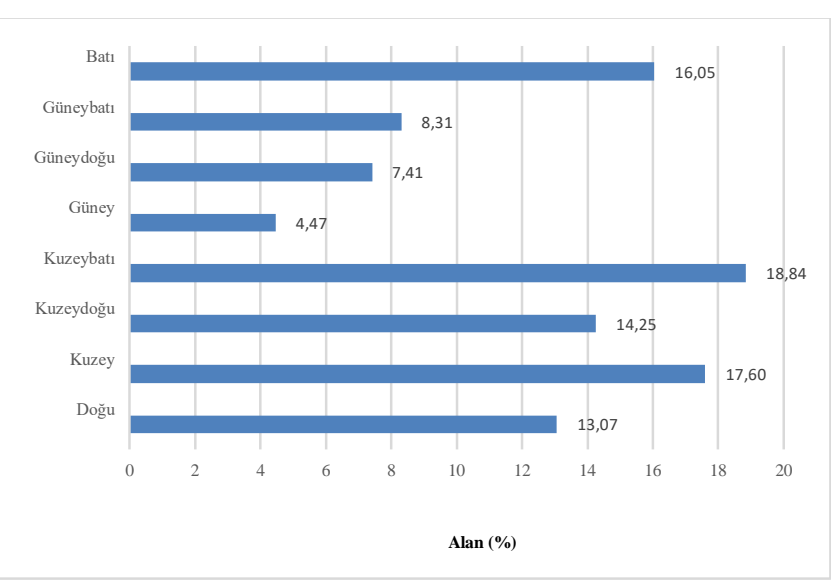

Şekil 6. Orman arazilerinin (ha) bakılara göre dağılımı. Figure 6. Distribution of forest lands (ha) by aspect.

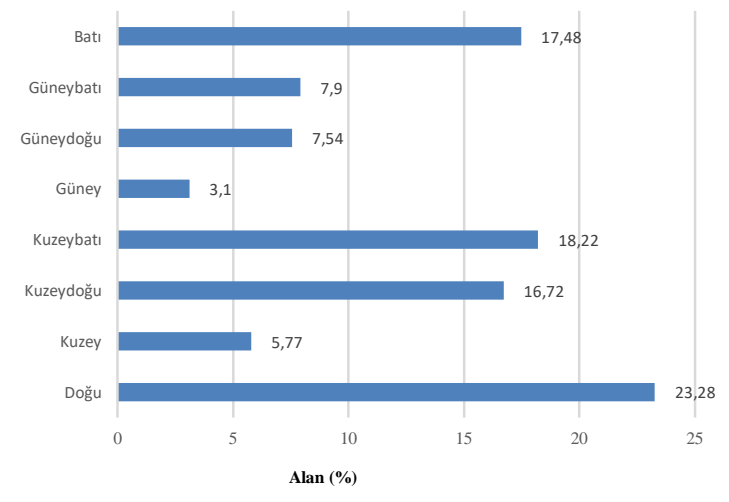

Şekil 7. Yerleşim yerlerinin (\%) bakılara göre dağılımı. Figure 7. Distribution of residential area (\%) by aspect.

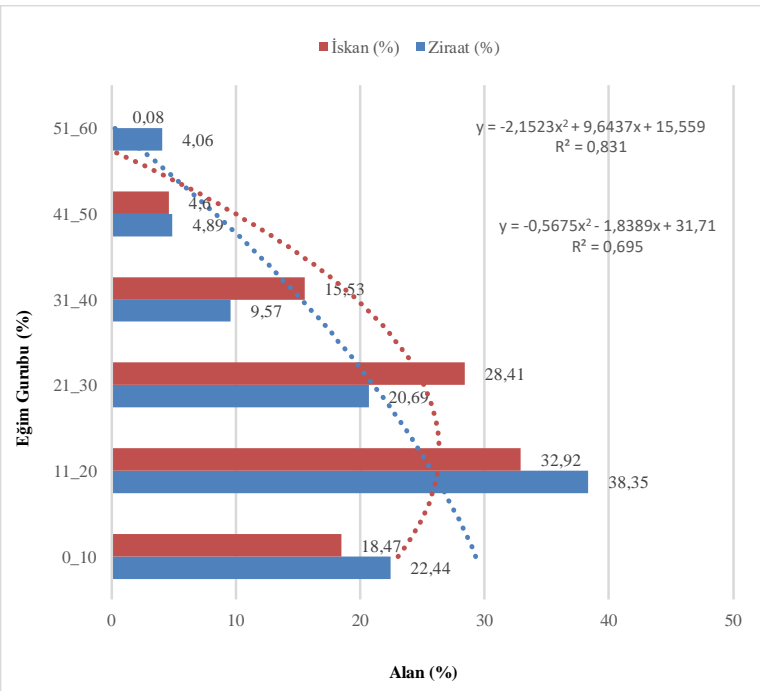

Şekil 8. Ziraat ve yerleşim alanlarının eğime göre dağılımı. Figure 8. Distribution of agricultural and residential areas by slope (\%).

\section{TARTIŞMA VE ÖNERILIER}

Ülkemiz genelinde en geniş arazi varlığı (toplam arazilerin \%18'i) 1000-1250 metre yükseltileri arasında ve Karadeniz bölgesindeki arazilerin \%16'sı 1000-1200 metre yükseltileri yer alırken (Elibüyük \& Yılmaz, 2010); Pazar Hemşin deresi havzasında en geniş arazi varlığı ülkemiz ve Karadeniz bölgesi ortalamalarına kıyasla daha alt yükselti kademesinde (900-1200 m) yer almaktadır. Yine Rize ilindeki farklı havzalarda arazilerin geniş alanlarda yayıldığı yükselti kademeleri birbirinden farklıdır. Çağlayan havzasında en geniş arazı \%13,54 ile 24012700 m yükselti basamağında (Yüksek vd., 2019), Firtına havzası firtına kolunda \%16,75 ile 2700-3000m yükselti basamağında ve Firtına havzası Durak alt havzasında $\% 12,02$ ile 600-900 m yükseltileri arasında yer almaktadır (Yüksek vd., 2020). Arazilerin sahip olduğu bu farklı özellikler Pazar Hemşin deresi havzasındaki arazi kullanım şekillerinin planlamasının bazı özellikleri itibariyle yerel, bölgesel hatta ulusal düzeydeki arazi kullanım planlamalarından farklı olabilir. Bununla birlikte Pazar Hemşin Havzasında bakıya göre arazilerin dağılımı Rize ilindeki Çağlayan ve Fırtına havzaları ile benzer özelliktedir. $\mathrm{Bu}$ havzalarda yapılacak doğal kaynak planlamalarında ve mevcut planların yönetim şekillerinde bakı faktörü benzer şekilde dikkate alınabilir. Türkiye ortalama eğiminin \%17,3 ve Karadeniz bölgesinin ortalama eğiminin \%26 olduğu dikkate alındığında (Elibüyük \& Yılmaz, 2010) Pazar Hemşin havzasının ortalama eğimi Türkiye ortalamasından 1,79, Karadeniz bölgesi eğim ortalamasından 1,19 katı daha yüksek bir eğime sahiptir. $\mathrm{Bu}$ nedenle doğal kaynakların sürdürülebilir planlanmasında eğim faktörü hem tek başına hem de diğer faktörler ile birlikte ele alınmalıdır. Pazar Hemşin havzası Karadeniz bölgesinin doğu kesimine (\% 34,8) (Elibüyük \& Yılmaz, 2010) kıyasla daha düşük bir ortalama eğime sahiptir. Pazar Hemşin havzasında toplam arazinin \%60,07'si \%0-30 eğim yer almaktadır. Karadeniz bölgesi genelinde en geniş arazi \%45,5 ile \%20-50, Doğu Karadeniz'de ise en fazla arazi \%51,03 ile \%20-50 eğim gurubunda yer almaktadır (Elibüyük \& Yılmaz, 2010). İlgili değerlerden görüleceği üzere Pazar Hemşin havzasındaki araziler Karadeniz bölgesi ortalamalarına ve Rize ilindeki iki büyük havzaya (Fırtına ve Çağlayan) göre daha az eğime sahiptir. $\mathrm{Bu}$ nedenle Pazar Hemşin havzasındaki arazi planlaması ve yönetiminde havza karakteristiklerinin Türkiye geneline göre daha hassas, Karadeniz bölgesi ve komşu havzalara kıyasla daha esnek olabilir. Ancak Pazar Hemşin havzasında doğal kaynakların (arazi kullanımı, yerleşim yeri seçimi, yol yapım çalışmaları, kentsel ve kırsal alan alt yapı çalışmaları, dere ıslahı ve sel-taşkın kontrol çalışmaları vb) sürdürülebilir planlanmasında eğim faktörünün doğru bir 
şekilde dikkate alındığı pek söylenemez. Yine eğim faktörünün yağış akış üzerindeki etkileri yeterince dikkate alınmadığı için havza genelinde sık aralıklarla sel, taşkın ve heyelan olayları meydana gelmektedir. 1973-2010 yılları arasında Pazar Hemşin deresi yağış havzasının da içinde olduğu Rize ili havzalarında 5 adet sel-taşkın olayında 48 kişi hayatını kaybetmiş ve milyonlarca liralık maddi hasar meydana gelmiştir (Yüksek, 2011). Karadeniz bölgesinin Doğu Karadeniz bölümünde olduğu gibi Pazar Hemşin havzası genelinde de I.+II.+III. Sınıf tarımsal arazi varlığ fazla değildir. Bu nedenle mecbur kalınmadıkça bu arazilerin tarımsal faaliyetler dışında kullanılmaması ve tarım dışı kullanımı konusunda ciddi kısıtlamalar getirilmesi son derece önemlidir. Küresel iklim değişiminin etkilerinin güçlü bir şekilde hissedildiği Rize ilinde benzer afetlerin yaşanmaması için planlamalarda eğim faktörü ve etkilerinin daha hassas bir şekilde dikkate alınmasının çok faydalı olacağı söylenebilir.

Tarım arazileri farklı tip kayaçlar, farklı yükselti ve eğim kademeleri ve bakılar üzerinde yer almaktadır. Tarım arazilerinin büyük çoğunluğunun \%10-30 eğim gurubunda yer alması arazi yetenek sınıflarının göz ardı edildiğinin açık bir kanıtıdır. Bir diğer önemli husus yüksek eğimli arazilerde arazi yetenek sınıflarının dikkate alınmadan tarım yapılması erozyon ve heyelan riskini daha da artırmaktadır. Havza genelinde meydana gelen heyelan olaylarının en çok tarım arazilerinde (çay ve mısır vb) meydana gelmesi bunun en açık kanıtıdır. Havzadaki tarım arazileri farklı agro-ekolojik zonlar üzerindedir. $\mathrm{Bu}$ nedenlerde tarım arazilerinin planlamasinda ve yönetiminde farklı özellikleri içerisinde barındıran bu agro-ekolojik zonların dikkate alınması gerekir. Böylece bir yandan tarım arazilerinden en yüksek miktar ve kalitede ürün elde edilirken; diğer yandan tarım arazilerinin sürdürülebilirliği güvence altına alınabilir.

Orman toplumlarının sürdürülebilir planlama ve yönetimlerinde kayaç guruplarının dikkate alınması gerekir. Çünkü kayaç guruplarının değişmesi toprak türü ve yapısının farklı olmasına neden olabilmektedir. Toprak türünün farklı olması ağaç türü seçiminde dikkate alınması gereken bir durumdur. Orman arazilerinin dağılımında gölgeli bakılar hakim durumdadır. Orman alanlarında ağaç türü seçimi, işletme şekli, idare süresi, toprak ve su koruma, vb çalışmalarının doğru bir şekilde planlanmasında bakı faktörü hassas bir şekilde dikkate alınmalıdır. Çünkü bakı faktörünün değişmesi ile birlikte yetişme ortamı özellikleri (toprak özellikleri, iklim özellikleri, vb) önemli ölçüde değişmektedir (Çepel, 1978). Bakı faktörünün hem münferit hem de diğer faktörler ile birlikte dikkate alınması, sürdürülebilir ormancıllğın ve sürdürülebilir arazi kullanımlarının güvence altına alınması için çok faydalı olabilir. Bunun sonucunda hem araştırma havzasında hem de Rize ve çevresindeki küresel iklim değişiminin olumsuz etkileri azaltılabilir.

Pazar Hemşin Havzası Türkiye'nin en yağış̧ı havzalarından biridir. Yerleşim yerlerinde bakı faktörünün doğru bir şekilde dikkate alınmaması, havza içerisinde drenaj sorunu yaşanmasına ve planlama çalışmalarında yağış-akış̧ ilişkisinin hatalı algılanmasına neden olmaktadır. Bütün bunların sonucunda havza genelinde çok ciddi sel, taşkın ve heyelan olayları meydana gelmektedir. Bu hususun hatalı algılanması, gelecekte çok daha şiddetli afetlerin havza içerisinde yaşanmasının olası olduğu görüşünü daha da kuvvetlendirmektedir. Yerleşim yerlerinin seçiminde eğim ve bakı faktörlerinin doğru bir şekilde dikkate alınmaması mesken ve işyerlerindeki 1sıtma ve soğutma giderlerinin de artmasına, nihayetinde ülkemiz enerji maliyetlerinin yükselmesine neden olmaktadır. Mesken ve iş yerlerinin oluşturulmasında bakı ve eğim faktörlerinin dikkate alınmamasının bir diğer önemli sonucu mekanların görsel kalitelerinin düşmesi ve yaşam ortamındaki sağlık koşullarının bozulmasıdır. Pazar Hemşin Havzası bol yağışlı olup yüksek oranda yağış akış değerine sahiptir. Bu nedenle yerleşim yeri planlama ve alt yapı ve iyileştirme çalışmalarında kayaç türleri mutlaka dikkate alınmalıdır. Doğal ortama ait jeomorfoloji (Boyraz \& Budak, 2017), tarihi ve sosyal şartlar (Yalçınlar, 1967), yükselti, eğim, bakı (Şahin \& Kaya, 2011), iklim (sıcaklık, nem, rüzgar, vb) (Gedikli, 2018) su, tarım arazisi, yol unsurları yerleşme yerlerinin seçimi ve konumlandırılmasında belirleyici rol oynadığ 1 pek çok araştırmacı (Karagel \& Karagel, 2010; Atasoy \& Özşahin, 2013; Esen \& Avc1, 2017) tarafindan belirtilmektedir.

\section{TEȘEKKÜR}

$\mathrm{Bu}$ çalışma kapsamında Rize İline ait ihtiyaç duyulan bazı coğrafi verilerin temini yönünde katkı sunan Karadeniz Teknik Üniversitesi Coğrafi Bilgi Sistemleri Laboratuvarı (KTÜ-GIS Lab) ekibine teşekkür ederiz.

\section{KAYNAKLAR}

Akkaya Aslan, Ş.T., Gündoğdu, K.S. \& Demir, A.O. (2004). Sayısal Yükseklik Modelinden Yararlanılarak Bazı Havza Karakteristiklerinin Belirlenmesi: Bursa Karacabey İnkaya Göleti Havzası Örneği. Ulud. Üniv. Zir. Fak. Derg., 18(1), 167-180.

Anonim. (2017). https://www.munichre.com/ en/risks/natural-disasters-losses-are-trendingupwards.html\#-1624621007 (21 Aralık 2020).

Atasoy, A. \& Özşahin, E. (2013). Yükseltiye Bağlı Olarak Nüfus Değişir mi? Hatay Örneği. Uluslararası Sosyal Araştırmalar Dergisi, 6(26), 92-108. 
Bağdatlı, C. \& Öztürk, B. (2014). Havza Morfolojik Özelliklerinin Belirlenmesinde Coğrafi Bilgi Sistemlerinin (CBS) Etkin Rolü. SAÜ Fen Bil. Der., 18(1), 11-19.

Boyraz, Z. \& Budak, E. (2017). Doğal Afetlerin Ayvalı (Darende / Malatya) Yerleşmesi Üzerindeki Etkileri. ZfWT, 9(3), 7-23.

Çepel, N. (1978). Orman Ekolojisi. İ.Ü. Orman Fakültesi Yayın No: 257, İstanbul, 534s.

Dengiz, O. \& Göl, C. (2008). Effects of physiographic factors and some soil hydro-physical soil properties on river follow in Uludere Catchment. Water Observation and Information System For Decision Support, (BALWOIS), Ohrid. Republic of Macedonia, 47-48.

Dindaroğlu, T., Özgül, M. \& Canpolat, M.Y. (2012). Sayısal Yükseklik Modeli Kullanılarak Bazı Havza Karakteristiklerinin Saptanması ve Arazi Kullanımı. KSÜ Mühendislik Bilimleri Dergisi Özel Sayl, 197-205.

Dutal, H. \& Reis, M., (2020). Determining the effects of land use on soil erodibility in the Mediterranean Highland Regions of Turkey: A case study of the Korsulu Stream Watershed. Environ Monit Assess, 192, 1-15. DOI: 10.1007/s10661-0208155-Z

Elibüyük, M. \& Yılmaz, E. (2010). Türkiye'nin Coğrafi Bölge ve Bölümlerine Göre Yükselti Basamakları ve Eğim Grupları. Coğrafi Bilimler Dergisi, 8(1), 27-55.

Eroğlu, H., Çetin, S., Erkan, M.A., Çamalan, G., Güser, Y., Odabaşı, E. \& Soydam, M. (2019). 2019 Y Ylı Meteorolojik Afetler Değerlendirmesi, Tarım ve Orman Bakanlığı, Meteoroloji İşleri Genel Müdürlüğü, Ankara. https://www.mgm.gov.tr/FILES/genel/kitaplar/2 019MeteorolojikAfetlerDegerlendirmesi.pdf. (Erişim: 14 Ocak, 2021).

Esen, F. \& Avcı, V. (2017). Tunceli İli'nde Topoğrafik Faktörlere Göre (Yükselti, Eğim, Bakı) yerleşmelerin ve nüfusun dağılışı. Uluslararası Sosyal Araştırmalar Dergisi, 10(51), 376-389. DOI: $10.17719 /$ jisr.2017.1774

Gedikli, B. (2018). Approaches to Climate Change in Spatial Planning and Design: International and Turkish Experiences. METU JFA, 35(1), 89-109. DOI: 10.4305/METU.JFA.2018.1.9

Göl, C. \& Dengiz, O. (2007). Çankııı-Eldivan Karataşbağı Deresi Havza Arazi Kullanım-Arazi Örtüsündeki Değişim ve Toprak Özellikleri. OMÜ Ziraat Fakültesi Dergisi, 22(1), 86-97.

Göl, C., Ediş, S. \& Yılmaz, H. (2017). Legal and Administrative Problems in Watershed
Management in Turkey: Case of Tatlıçay Watershed. Environmental Engineering and Management Journal, 16(12), 2685-2698. DOI: 10.30638/eemj.2017.279

Karagel, H. \& Karagel, D.Ü. (2010). Devrek ilçesinde yerleşmelerin kuruluş yeri seçiminde etkili olan coğrafi faktörler. E-Journal of New World Sciences Academy, 5(2), 4A0022, 76-97.

Özhan, S. (2004). Havza Amenajmanı. İ.Ü. Orman Fakültesi Yayın No: 481, İstanbul 385s.

Reis, A. \& Dindaroğlu, T. (2018). Havza ölçeğinde bazı ekohidrolojik karakteristikler ile arazi kullanım ilişkilerinin araştırılması: Bertiz Çayı yağış havzası örneği. Turkish Journal of Forest Science 2(1), 68-82. DOI: 10.32328/turkjforsci.413309

Reis, A. \& Dindaroğlu, T. (2020). Havzalarda Bazı Hidrolojik Karakteristiklerin Archdyro Yazılımı Kullanılarak Belirlenmesi. Turkish Journal of Forest Science, 4(1), 146-159. DOI: 10.32328/turkjforsci.706568

Reis, M., Bolat, N., Dutal, H. \& Abız, B. (2017b). producing erosion risk map using remote sensing techniques and RUSLE method in Halfalı Stream Catchment of Kahramanmaras. Kastamonu Uni., Orman Fakültesi Dergisi, 17(1), 176-185.

Reis, M., Dutal, H., Abiz, B. \& Bolat, N. (2016). Kahramanmaraş ili Göksun ilçesi'nde arazi kullanımında meydana gelen zamansal değişimin uzaktan algilama teknikleri ve coğrafi bilgi sistemi ile belirlenmesi. KSU Mühendislik Bilimleri Dergisi, 19(2), 35-41. DOI: 10.17780/ksujes.91496

Reis, M., Dutal, H., Bolat, N. \& Savacı, G. (2017a). Soil Erosion Risk Assessment Using GIS and ICONA: A Case Study in Kahramanmaras, Turkey. Journal of Agricultural Faculty of Gaziosmanpasa University, 34(1), 64-75. DOI: 10.13002/jafag4208

Şahin, K. \& Kaya, M. (2011). Yerleşmeler üzerinde bakı faktörünün etkisi: Sinop şehri örneği. Uluslararası Sosyal Araştırmalar Dergisi, 4(19), 379-387.

Shen, G., \& Hwang, S.N., (2019). Spatial-Temporal Snapshots of Global Natural Disaster Impacts Revealed From EM-DAT for 1900-2015, Geomatics, Natural Hazards and Risk, 10:1, 912934. DOI: $10.1080 / 19475705.2018 .1552630$

Taş, E. (2016). Coğrafi bilgi sistemleri yardımıyla havza karakteristiklerinin belirlenmesi: Afyonkarahisar Çay deresi havzası. International Academic Research Congress, Antalya. Türkiye, 603-610. 
Yalçınlar, İ. (1967). Türkiye'de bazı şehirlerin kuruluş ve gelişmesinde jeomorfolojik temeller. $\dot{I} . \ddot{U}$. Coğrafya Enstitüsü Dergisi, 16, 53-66.

Yazıcı, N., Babalık, A.A. \& Dursun, İ. (2019). Jeolojik Kökenli Doğal Afetler İçinde Heyelanların Yeri ve Önemi. 3. Uluslararası Bilimsel Çalışmalar Kongresi (UBCAK), Antalya, Türkiye, 231-238.

Yazıcı, N. \& İnan, B. (2020). Determination of temporal change in land use by geographical information systems: The case of Çandır village of Turkey. Fresenius Environmental Bulletin, 29(05), 35793593.

Yılmaz, H., Göl, C. \& Ediş, S. (2011). The importance of watershed characteristics in integrated watershed management (A case of Gökdere Watershed, TURKEY). Fresenius Environmental Bulletin 20(12), 3126 - 3134.

Yüksek, T. (2001). Rize-Pazar Deresi Yă̆ı̧̧ Havzasında Farklı Arazi Kullanım Şekilleri Altındaki Toprakların Bazı Özellikleri İle Aşınım Eğilimi Değerlerinin Araştırılması. Doktora Tezi, Karadeniz Teknik Üniversitesi, Fen Bilimleri Enstitüsü, Trabzon, Türkiye, 204s.

Yüksek, T. (2004). Türkiye'nin su kaynakları ve havza planlamasına dönük genel değerlendirmeler. $K A \ddot{U}$ Artvin Orman Fakültesi Dergisi, 1(2), 71-83.

Yüksek, T. (2011). Rize Yöresinde Yanlış Arazi Kullanımı ve Neden Olduğu Çevresel Sorunlar. Doğu Karadeniz Bölgesi Heyelan ve Taşkın Sempozyumu, Trabzon. http://www.dsi.gov.tr /docs/sempozyumlar/1-4-rize-y\%C3\%B6resindeyanl\%C4\%B1\%C5\%9F-arazi-kullan\%C4\%B1m $\% \mathrm{C} 4 \% \mathrm{~B} 1-\mathrm{ve}-\mathrm{neden}$-oldu\%C4\%9Fu-\%C3\%A7 evresel-sorunlar---yrd-do\%C3\%A7-dr-turany\%C3\%BCksek.pdf?sfvrsn=2.

Yüksek, T. (2017). Rize ili arazi kullanım durumu, bazı ormancıllk çalışmaları ve yağıșların zamansal dağılımının genel bir değerlendirilmesi. Anadolu Çevre ve Hayvancılık Bilimleri Dergisi 2(3), 5966.

Yüksek, T., Cengiz, T. \& Yüksek, F. (2008). Doğal alanlarda festival etkinliklerinin korumakullanma açısından değerlendirilmesi: Kafkasör Kültür, Sanat ve Turizm Festivali Örneği, Ekoloji, 17(67), 37-45.

Yüksek, T., Özçelik, A.E. \& Verep, B. (2020). Fırtına havzasının bazı havza karakteristikleri ile arazilerin fizyografik özelliklere göre dağılımlarının coğrafi bilgi sistemleri ile belirlenmesi. Anadolu Çevre ve Hayvancllk Bilimleri Dergisi, 5(3), 439-449. DOI: 10.35229/jaes.792606
Yüksek, T., Özçelik, A.E. \& Verep, B. (2019). Çağlayan havzasının (Findıkl1-Rize) bazı havza karakteristiklerinin coğrafi bilgi sistemleri ile değerlendirilmesi. Anadolu Çevre ve Hayvancllk Bilimleri Dergisi, 4(3), 532-538. DOI: 10.35229/jaes.648366

Yüksel, A., Demir, Y., Sürücü, A., Kolak, N. \& Hopur, B. (2018). Flood control studies and soil protection measures of the Han-El Ba'rur (Gök Deresi) Microcatchment on Tek Tek Mountains, Harran. 1. International GAP Agriculture \& Livestock Congress, Şanliurfa, Türkiye, 10351040.

Yüksel, A., Gündogan, R. \& Akay, A.E. (2008). Using the remote sensing and GIS technology for erosion risk mapping of Kartalkaya Dam Watershed in Kahramanmaras, Turkey. Sensors, 8, 4851-4865. DOI: $10.3390 / \mathrm{s} 8084851$ 